\title{
THE GERMAN VIEW ON MODERNISM AND POSTMODERNISM
}

\begin{abstract}
This article examines the origins of modernism/postmodernism and their presentation in the light of aesthetic and philosophical treatises or literary works of Friedrich Schlegel, Heinrich Kleist, Friedrich Schiller, as well as in the triad model of the world history and the biblical story of the fall of the man. The common idea which lies at the basis of the works presented is the contrast between the principles of nature and reason and the search for opportunities for their synthesis. The central thesis of the article is to present the commonality between the maxims of modernism/postmodernism and early German romanticism, as well as to consider postmodernism as late romanticism with its inherent manneristic features. The basic concepts of modernism and postmodernism are presented through the prism of works and theories of Friedrich Nietzsche, Wolfgang Welsch, Christoph Bode, Rolf Günter Renner, as well as Victor Žmegač. The central concept in the article is the concept of self-reflection of literature and art as the most vivid feature of modernism and postmodernism.
\end{abstract}

Keywords: nature and reason, romanticism, modernism, postmodernism self-reflection of art.

"Thus, what could lead to postmodernism once again ends... in romanticism"

(Welsch, 1987, p. 176).

Introduction

Friedrich Schlegel had already referred to a historical-philosophical differentiation between 'antiquity' and 'modernity' in his early text "About the Study of Greek Poetry". Schlegel proceeds from the assumption here that antique art is the manifestation of a 'natural' connection between the self and the world, while modernity is characterized by the emancipation of the reason, which analytically separates, distinguishes and criticizes things. The world of antiquity, shaped by the self-evident connection of all things, is breaking apart, an open development comes along: the unity of modern (progressive) art could only be produced by the reason. Thus, the reason has to try to create unity through a new analytical operation, by turning back to itself $^{1}$, which has destroyed itself through its analytical nature. For Schlegel (1980), modern art in this sense is always and necessarily a 'meta-art' (p. 109).

The separation of nature and spirit goes back to the triadic model of the world history postulated in modern times by both: the classics and the early Romantics. This model is based on a historical-philosophical-abstractly conceived sequence of times: the first stage of development

1 We understand it in the wide sense of the word as the self-reflection of art. 
forms the so-called "Golden Age", its middle phase stands for alienation from nature, and the third stage symbolizes the ideal state, which is a reflected synthesis of the first and second ages. The "Golden Age" characterizes, in particular, the still unreflected and therefore self-evident unity of nature and man. The second phase stands for the modern present, namely the conflict with nature, which has arisen because of the exclusive orientation of man towards intellect and science. The future third phase is presented as a conscious and reflexively potentiated harmony with nature, in which man is to achieve harmony with himself.

In this regard, Friedrich Wilhelm Joseph Schelling emphasizes the free will of man, and he sees the goal of world history in the fact that man faces up to the task of his own free will: The painful development of the Godhead comes to its end, and everything, redeemed from humanity, enters the eternally unmoved rest of the Godhead. Thus, nature and spirit would again form a unity and no longer oppose each other as opposites (Wührl, 1998, pp. 79-86).

Another model for the origins of language scepticism as a characteristic of the modern age is offered by the biblical story, where the state of innocence in the Garden of Eden can be compared to the "Golden Age". After eating from the Tree of the Knowledge, man could distinguish between good and evil, which, on the other hand, is paralleled with the awakening of human consciousness. Thus, the following phase can be equated with alienation, excess of consciousness and over-reflexivity, which stood in the way of the time of harmony, originality, creativity, the immediate creation in art. With the mortal sin for humankind, the death of naivety and sterility in art occurred, which is most clearly expressed in the modern era: "In terms of the "word" or lan- guage, this means that, as modernism also correctly states, the authenticity and immediacy of expression has been lost in the face of increasing distance and over-reflexivity..." (Stürmer, 2013, p. 202).

\section{Main Text}

The notion of the crisis of art, triggered by an excess of reflexivity, is also problematized in Heinrich Kleist's essay “About the puppet theatre" („,̈ber das Marionettentheater“). His reflections in this regard again revolve around the tree of the Knowledge. In his essay, Kleist (1990) pursues the idea of "the disorder that consciousness causes in the natural grace of man" (p. 560), and links this to the assertion that "since we have eaten from the tree of the Knowledge" (p. 559), humans can achieve nothing in art any more. Kleist concludes that "paradise is locked and the cherub is behind us; we must make the journey around the world and see whether it is perhaps open again from behind somewhere" (p. 559). The conclusion of Kleist is as follows: "when knowledge has passed through an infinite as it were", there will again be a possibility "to fall back into the state of innocence" (p. 563).

Friedrich Schiller's treatises "On the aesthetic education of man in a series of letters" („Über die ästhetische Erziehung des Menschen in einer Reihe von Briefen", 1795) and in "About naive and sentimental poetry” (,Über naive und sentimentalische Dichtung“", 1795/96) had a particular influence on the aesthetic discourse of modernity. According to his "Aesthetic Letters", Schiller (2004) postulates the transition from the "natural state" via the "state of freedom" to the "state of reason" (p. 647). The three stages symbolize the aesthetic education of man. While the state of nature is coupled with material needs, the 
second stage of aesthetic education focuses on moral values. In the third state, man can control both sides equally, whereby the aesthetic state is both path and goal at the same time. Schiller also makes a distinction here between antique and modern society, characterizing the former as an ideal one. Modern society, on the other hand, he attests to the loss of inner freedom. ${ }^{2}$

According to Schiller, modern social orders, because of their particularization, resembled a "coarse mechanics..., where a mechanical life as a whole is formed from the fragmentation of infinitely many, but lifeless parts." (Schiller, 2004, p. 583) "Schiller considers reflexivity to be guilty of this development", because "the alldividing mind" struck "this wound to the new humanity..., so the inner bond of human nature is also torn apart, and a perishable quarrel tore its harmonious powers apart" (Schiller, 2004, p. $583)^{4}$.

The aim of aesthetic education is, therefore, that man should do the morally correct thing no longer out of duty, as the result of a rational process, but out of affinity. This model, in turn, leads to a political goal, i.e. "refinement of character" (Schiller, 2004, p. 592) . $^{5}$ A cultural stage of development in this respect would promise that sensuality and morality come to a balance so that the right thing is wanted of its own accord.

Thus, he succinctly sums up the function of art in modernity: the responsibility of art is to put an end to the deficient general condition in which the individual and all of humanity find themselves in modernity. So, it can be concluded that Schiller sees art as a bringer of salvation (but not in the religious sense), but its sphere of activity

2 Nietzsche, too, regards modernity as an experience of loss.

3 The $6^{\text {th }}$ letter.

4 The $6^{\text {th }}$ letter.

5 The $8^{\text {th }}$ letter. should not be limited to its own sphere but should take on a task for society as a whole.

The already mentioned treatise "About Naive and Sentimental Poetry" (1795) focuses not only on a different world view of artists but also on different types of poets (intuitive versus reflexive). At the centre of this treatise by Schiller is the concept of nature, which he defines as "nothing other than voluntary existence, the existence of things by themselves, existence according to their own and independent laws" (Schiller, 2004, p. 694.) and at another point as “...eternal unity with itself” (Schiller, 2004, p. 695). Nevertheless, Schiller realizes that this view of nature can only be regarded as an ideal for modern man, in other words as a "realization of the ideal" (Schiller, 2004, p. 697).

Schiller makes the following demand of the sentimental poet: "He does not lead us backwards into our childhood in order to let us buy a rest with the precious acquisitions of the intellect, which cannot last longer than the sleep of our mental powers; but leads us forward to our maturity in order to give us the feeling of higher harmony" (Schiller, 2004, p. 750).

Schiller thus draws a differentiated dividing line between the two types of poetry, saying that the poets "belong either to the naïve or to the sentimental" (Schiller, 2004, p. 712): "The poet, I said, is either nature or he will seek it. One makes the naive poet, the other- the sentimental poet." (Schiller, 2004, p. 716) [Emphasis in text]. The naive poet is characterized by the fact that he is still connected with the ideal of the state of nature. His unbroken and immediate perspective on the world is derived from this. The sentimental poet is, as the quote says, a seeker of the ideal of the state of nature because he is aware of the break between the ideal and reality. This means that sentimental poetry is no longer mere 
mimesis but also includes reflection. Since the ideal is something unattainable, Schiller is concerned with an infinite approach to the ideal: "But because the ideal is infinite that he never reaches, the cultivated man can never become perfect in his own way, just as the natural man can become perfect in his own" (Schiller, 2004, p. 718). It follows: in order to achieve the goal of history, namely the balance of common sense and sensuality, it is necessary that art also contains both sides, only a reflected view of modernity can lead to its overcoming. Thus, according to Schiller, the sentimental artist is assigned the task of educating people aesthetically and thus overcoming the deficient modernity.

The following statement succinctly sums up the above-mentioned statements, and concerns the approach of the present investigation: For here Schiller addresses the task of the modern subject, which can also be applied to the modern poet. He writes, for example, that it is "of infinite importance for the modern subject to look again at the legislation of nature in a pure copy and to be able to purify himself from the depravities of art in this mirror" (Schiller, 2004, p. 747) [Emphasis: Y. E.]. In this, we see the above-quoted demand on art to mediate between rationality and sensuality as the two sides of art.

On the first of January 1887, the "Allgemeine Deutsche Universitätszeitung" published ten "theses of the free literary association 'Durch'!" The sixth thesis said: "Our highest artistic ideal is no longer antiquity, but modernity" (Wunberg \& Dietrich, 1998, pp. 23-24). In literary studies, the definition of modernity is mostly used historically: It encompasses the artistic movements of the late 19th and early 20th

\footnotetext{
This is the first use of the - older - term "modern" in the sense of a current epoch term. In the past, the term had usually been used in a much more general sense, in contrast to the term of antiquity.
}

centuries and is seen as a pluralistic movement. "The basis for the connotation of 'modern' in the Age of Enlightenment and Romanticism, i.e. in the age of world-historical modernity (in Habermas' sense), is the awareness of the unpredictable changeability of history and thus of a potentiality of occurrence, within which the own new can have a chance" (Žmegač, 1987, p. 252).

It should be noted that since the 18 th century the present has been described as "modern", which then caused confusion in the use of the term "modernity". Hans Robert Jauß (1970) points out that that the word "modernism" was already used in the fifth century, "in the period of transition from ancient Rome to the new Christian world" (p. 16). He regards modernity less as an epochal concept than as the expression of a specific consciousness. For Baudelaire, modernity is an expression of contemporaneity. It is true that even today, we still use the word "modern" colloquially often only in the sense of "present, current". Baudelaire also means it, but he adds a normative emphasis: we should live in the present, not indulge in romantic dreams of the past. "For Baudelaire, aesthetic and historical experience of modernité fall into one" (Jauß, 1970, p. 55).

Modernity is classified as a crisis phenomenon from the very beginning. The liberation from this crisis is seen in radical modernity. The ambivalent character of the concept of modernity is demonstrated by Dieter Borchmeyer (1986, pp. 176-183) in the concept of Décadence, namely in "Nietzsche's critique of Décadence". Thus, the latter writes in the "Case of Wagner": "I am as good as Wagner the child of this time, that is, a decadent: only that I understood that only that I resisted it" (Nietzsche, 1999, p. 11). It follows that Nietzsche regards himself as a sceptical contemporary of modernity, a time, characterised by 
him as decay. This makes him a decadent artist. Since he nevertheless sees through the state of decay, he can defend himself against it by rejecting the latter. The decadence of his time is associated with the loss of a tradition. After all: "the relativization of meanings and values does not mean that they no longer mean anything at all; rather, it means that they can mean something else, possibly everything else" (Wunberg, 1995, p. 60). In the modern age, the amount of traditional knowledge is so present that it is perceived as ballast. For this reason, Nietzsche demands that the "historically sick" be forgotten. On the other hand, "remembering is to be understood as the complement of forgetting and as a condition of the present" (Barner, 1989, p. 10). In other words, one could maintain that only the absolutely new is still suitable for art, which is summarized by the word "novity". This calls into question the transformability of traditional content.

As soon as the writer considers that the source of creation is not nature but art, he begins to reflect on it. It thus depends on whether a writer perceives the respective tradition as ballast that could lead him to silence, or as the innovative potential that serves as a fundus. These approaches are reflected in the language. The epistemological crisis of modernity is related to the catchwords loss of reality, disintegration of values and alienation and is linked to the results of science: Quantum mechanics and the theory of relativity lead to the loss of confidence in the objectivity of human perception. The failure of logocentrism, the experience of a border between the self and the world, the doubt about the ability of language to carry meaning, thus trigger two attitudes that are the consequence of language scepticism: the silence in speechlessness and the playful use of language. The interrupted flow of what is written, the slowing down, the fragmen- tation of the text as a whole are related to a reality that can no longer be caught up by pure description. Incoherence, in reality, brings incoherence in literature. This also results in the loss of the mimetic ability of language. David Lodge (1981) summarizes the characteristics of modern literature as follows: "formal experiment, dislocation of conventional syntax, radical breaches of decorum, disturbance of chronology and spatial order, ambiguity, polysemy, obscurity, mythopoetic allusion, primitivism, irrationalism, structuring by symbol and rather than by narrative or argumentative logic, and so on" (p. 71).

Doubt about the truth of the word is growing into a common topos of modern literature par excellence. The language crisis and the associated identity crisis take place in the reflexive act of writing. It follows that the loss of language can be spoken or written about in the same way. This brings the creation of the work of art into the focus of literature. This happens through the break with the literary tradition that practised a meaningful narrative.

Alice Bolterauer (2007) describes the "forced form of reference to one's own writing in the various forms of self-reference and self-reflection in the context of a reflection on literary modernity... as a sign of modernity", referring to both Theodor Adorno and Niklas Luhmann (p. 176). ${ }^{7}$ In another treatise on the "literary-theoretical reflections of Viennese modernism, Bolterauer describes the crisis of legitimacy in which literature around 1900 finds itself, which can,

7 Cf. ibidem: "So not only Theodor W. Adorno thinks that the artists of modernity are "compelled to permanent reflection" (Theodor W. Adorno, Ästhetische Theorie, p. 507), Niklas Luhmann also speaks of the necessity of a "reflection of the form of self-observations and self-descriptions of a system, which have to be proposed and enforced in the system itself in a process which in turn is again observed and described" (Niklas Luhmann, Beobachtungen der Moderne, p. 7f). 
however, be applied to pan-European, including German-language literature: "Themes, modes, media and functions seem to have been lost to it [literature. Note Y. E.]. The competition of new scientific disciplines (e.g. psychology) and technical achievements (the 'new' media) threatens to restrict the scope and meaning of literary writing existentially. 'Old' patterns of explanation and justification are proving to be exhausted, new paradigms of writing and its social anchoring are not in sight. In this situation, it is not surprising that the concept of literature itself is disappearing. What literature is in itself, whether 'the' poetry exists at all: it is in these doubts that a precarious consciousness of the authors of what they write and of themselves crystallizes." (Bolterauer, 1998, p. 14).

As a result, there is a permanent self-questioning and critical problematization of literary and aesthetic norms. Under the given circumstances, the concept of literature proves to be a constructed, newly designed and defined - in short: a progressive process.

In his study "Poeticity", Sebastian Neumeister (1970, p. 50) addresses the fact that the phenomenon of "self-reflection of art" has become a more frequent theme in the $20^{\text {th }}$ century. Manfred Schmeling (1977) notes the following: "The principle is clear: literature no longer knows anything but itself, it ultimately only questions itself about its own functioning, form becomes content" (p. 5).

In his study "Our Postmodern Modernity", Wolfgang Welsch (1987) shows how the critic of modernity becomes an overcomer of "modern illness" by opposing modern intensification with a postmodern attitude: "For now one could no longer manoeuvre new projects ever into the world in the name of truth, but had to reckon with the return of the same - after the mask character had been seen through" (p. 137).

Ambiguity is elevated to a strategy of postmodernism, which means that the past (in the sense of tradition) is not simply overcome, but transformed, appropriated and perspectively broken. Ambiguization can be interpreted on the one hand as the result of the language crisis, but on the other hand, as creative potentiality and plurality. In his dissertation "Aesthetics of Ambiguity”, Christoph Bode considers ambiguity not only as a characteristic of modern art but as a paradigm of modernity per se. In doing so, he opposes postmodernist talk of the end of modernity, since, in his view, neither the literary material nor supposedly radical textual techniques justify talk of the age of postmodernity: “...because exactly that which is presented as radically new is nothing more than the practical testing of the rules of modernity: ambiguity through self-reference. Literary ambiguity as to the mark of modernity, also characterizes "postmodern literature" (Bode, 1988, p. 315).

Bode regards postmodernism as a dialectical component of modernism and considers it superfluous as an epochal literary concept. Rolf Günter Renner (1988), who investigates the special characteristics of postmodernism, also sees "the postmodern constellation... prepared in the norms and settings of modernity" (p. 124). Following Bode (1988), we do not consider postmodernism as an epochal literary concept, but as a practice of "practical testing of the rules of modernity" on literary works. At the bottom of this article is the thesis that postmodernism is the late romantic phase of literary modernity with its typical mannerisms and exaggerations. It has a lot in common with the high phase but is much more critical and extreme, but above all, self-reflexive 
- in Bode's sense "ambiguated by selfreference" (p. 315).

The plurality criticized by Nietzsche, because it ends in arbitrariness, becomes the flip side of modernity, which, for representatives of postmodernist theories, relies on novity (novelty). Accordingly, it could be concluded that modernity and postmodernity differ in their handling of material. For this reason, this article will not consciously speak of epochs here. Postmodernism is the name of a process that brings the complexity and ambiguity of a work of art into the field of interpretation and construction. On the other hand, it is, like modernism, the expression of a specific consciousness that, in dealing with the material of tradition, focuses on plurality and the suspension of strategies.

Wunberg (1983) has already proven for modernity that the daily information overload has led to the complaint about the loss of unity. Paradigmatically for the present attitude towards life, this results in the simultaneity of the nonsimultaneous. It leads to the awareness that one can judge only partially and only from a particular perspective. Wolfgang Welsch and Christoph Bode agree that postmodernism does not strive to overcome modernity or to become transomdern. Welsch (1987) goes even further by investigating how the artists' position on their material has changed: "Postmodernism exists where a fundamental pluralism of language, models, methods is practised, not just in different works side by side, but in one and the same work, i.e. interreferentially" (pp. 16-17).

Thus, plurilingualism is created as a coexistence of different languages, and the difference is brought to the fore. The representatives of postmodernism see the notion of wholeness as a deception, the loss of meaning is transformed into a perspective of undreamt-of possibilities, into the generation of multiple meanings.

As already mentioned, postmodernism is not an overcoming of modernity, but rather its continuation and reversal of the signs. It is also essential to draw a dividing line between its relationship to tradition. For postmodernism, forms and values may still have generally accepted validity, but they no longer have any general binding force: "Old can be younger than young, can ignite more present and future than the permanent glow of the current contains. It can, but does not have to. No precedence for tradition" (Welsch, 1987, p. 106). Viktor Žmegac (1985) notes this: "The uncertainty about reality is revealed in the authors' tendency to replace the older narrative models suggesting a totality of experience, for example in the tradition of the development novel, with mosaic-like descriptions of conditions" (p. 278).

Ambiguity always arises when literature seeks to escape its primary meaning. This creates a suspension between normal, metalinguistic and aesthetic levels of meaning. Ambiguity does not degrade into a stylistic device but rather represents an effect of aesthetic textualization.

\section{Conclusions}

The argumentation of this investigation boils down to the fact that the rediscovery of the self-reflexive gesture in modernity and its intensification in postmodernity can be traced back to the crisis of modernity, namely to the loss of meaning and the associated language crisis. The latter, consecutively, leads not only to the triadic model of the word history and the biblical myth about the fall of man but also to the observations about the loss of unity and harmony, as presented by Friedrich Schiller and Heinrich Kleist. From this, an extensive arc spans, whose philosophical 
beginnings lead back to early Romanticism and end in postmodernism as a particular aesthetic approach. In its turn, this is reflected in the process of the self-reflexive act of writing, when the conditions under which a literary work is created: thus, the writing process itself comes to the forefront of contemplation. The further parallels between Romanticism as a spiritual position and postmodernism are particularization in representation (it is reflected in the fragments as a literary genre in Romanticism), the abolition of temporal chronology, the intensification of attention to mosaic representation, which in turn is connected with the loss of totality. The search for totality is reflected in the fact that writing becomes a dialectical and never-ending process.

\section{REFERENCES}

Bode, Ch. (1988). Ästhetik der Ambiguität. Zur Funktion und Bedeutung von Mehrdeutigkeit in der Literatur der Moderne. Tübingen: Niemeyer.

Barner, W. (Hg.) (1989). Tradition, Norm, Innovation. Soziales und literarisches Traditionsverhalten in der Frühzeit der deutschen Aufklärung. München: R. Oldenbourg.

Bolterauer, A. (2007). Selbstreferenz und Selbstreflexion als Ausdruck eines krisenhaften Moderne-Bewusstseins diskutiert am Beispiel der, Wiener Moderne'. In J. Hauthal (Hg.), Metaisierung in Literatur und anderen Medien: Theoretische Grundlagen - Historische Perspektiven - Metagattungen - Funktionen (S. 175-193). Berlin u.a.: De Gruyter.

Bolterauer, A. (1998). Die Literatur, gibt es sie überhaupt? Die literaturtheoretischen
Reflexionen der Wiener Moderne. Newsletter Moderne. Zeitschrift des Spezialforschungsbereich Moderne Wien und Zentraleuropa um 1900, 1(1), 14-16.

Borchmeyer, B. (1986). „Nietzsches DécadenceKritik“. In W. Barner und W. Haug (Hg.), Ethische contra ästhetische Legitimation von Literatur. Traditionalismus und Modernismus: Kontroversen um den Avantgardismus. Akten des 7. Internationalen Germanisten-Kongresses. Göttingen 1985. Bd. 8 (S. 176183). Tübingen: Niemeyer.

Jauß, H. R. (1970). Literaturgeschichte als Provokation. Frankfurt a. M.: Suhrkamp.

Kleist, H. v. (1990). Über das Marionettentheater. In Heinrich Kleist, Sämtliche Werke und Briefe in vier Bänden (S. 555-563). I.-M. Barth u. K. Müller-Salget (Hg.). Bd. 3. Frankfurt a. M.: Dt. KlassikerVerlag.

Lodge, D. (1981). Historicism and Literary History: Mapping the Modern period. In David Lodge, Working with Structuralism (pp. 68-75). Boston u.a.: Routledge \& K. Paul.

Neumeister, S. (1970). Poetizität. Heidelberg: L. Schneider.

Nietzsche, F. (1999). Sämtliche Werke. Kritische Studienausgabe in 15 Bänden. B.6. G. Colli und M. Montinari (Hg.). München: dtv.

Renner, R. G. (1998). Die postmoderne Konstellation. Theorie, Text und Kunst im Ausgang der Moderne. Freiburg: Rombach.

Schiller, F. (2004). Die ästhetische Erziehung des Menschen in einer Reihe von Briefen (1795). In F. Schiller, Sämtliche 
Werke in 5 Bänden. Auf der Grundlage der Textedition von Herbert G. Göpfert. P.-A. Alt, A. Meier und W. Riedel (Hg.). Bd. 5. Erzählungen, theoretische Schriften. W. Riedel (Hg.). München: dtv.

Schlegel, F. (1980). Literarische Notizen 17971801. H. Eichner (Hg.). Frankfurt a.M. u.a.: Ullstein.

Schmeling, M. (1977). Das Spiel im Spiel. Ein Beitrag zur vergleichenden Literaturkritik. Gütersloh: Schäuble.

Stürmer, F. (2013). Künstler zwischen Tod und Teufel. Sprache und Sprachkritik im Doktor Faustus. In K. Max (Hg.), Wortkunst ohne Zweifel? Aspekte der Sprache bei Thomas Mann (S. 201221). Würzburg: Königshausen und Neumann.

Welsch, W. (1987). Unsere postmoderne Moderne. Weinheim: VCH, Acta Humanoria Verlag.
Wunberg, G., \& Dietrich, St. (Hg.) (1998). Die literarische Moderne. Dokumente zum Selbstverständnis der Literatur um die Jahrhundertwende. 2. Aufl., Freiburg i. Br.: Rombach.

Wunberg, G. (1995). Historismus, Lexemautonomie und Fin de siècle. Zum Décadence-Begriff in der Literatur der Jahrhundertwende. Arcadia, 30, 31-61.

Wunberg, G. (1983). Wiedererkennen. Literatur und ästhetische Wahrnehmung in der Literatur der Moderne. Tübingen: Niemeyer.

Wührl, P.-W. (1998). Erläuterungen und Dokumente: E.T.A. Hoffmann - Der goldene Topf. Stuttgart: Reclam.

Žmegač, V. (1987). Moderne/Modernität. In D. Borchmeyer und V. Žmegač (Hg.), Moderne Literatur in Grundbegriffen (S. 278-286). Frankfurt a. M.: Athenaeum. 